\title{
Effect of Sodium Cyclamate on the Rat Fetal Liver: A Karyometric and Stereological Study
}

\author{
Efectos del Ciclamato de Sodio en el Hígado Fetal de Ratas: \\ Estudios Cariométrico y Estereológico
}

\begin{abstract}
"Alex Tadeu Martins; "Reinaldo Azoubel; **Ruberval A. Lopes; *"Miguel A. Sala di Matteo \& "José Germano Ferraz de Arruda
\end{abstract}
MARTINS, A. T.; AZOUBEL, R.; LOPES, R. A.; DI MATTEO, M. A. S.; ARRUDA, J. G. F. Effect of sodium cyclamate on the rat fetal liver: A karyometric and stereological study. Int. J. Morphol., 23(3):221-226, 2005.

SUMMARY: The cyclamate, a sweetner substance derived from $\mathrm{N}$-cyclo-hexyl-sulfamic acid, is largely utilized as a non-caloric artificial edulcorant in foods and beverages as well as in the pharmaceutical industry. The objective of this study was to evaluate fetal hepatic karyometric and stereological alterations in the rat fetal liver resulting from the intraperitoneal administration of sodium cyclamate. The livers of ten rats were evaluated, five treated and five controls chosen at random, in which five rats that received from the 10th to 14th days of pregnancy an intraperitoneal daily injection of sodium cyclamate at $60 \mathrm{mg} / \mathrm{Kg}$ of body weight during 5 days. At the 20 th day of gestation, the animals were removed and weighed, as were their placentas, on a precision balance; the length of the umbilical cords also were measured. After the laboratory processing, semi-seriated $6 \mathrm{~mm}$ cuts stained with haematoxyline and eosine were performed. In seven karyometric parameters (major, minor, and medium diameters, volume, area, perimeter, and volume-area ratio), the increase was statistically significant in the treated group when compared with control group. Stereological parameters showed in the treated group a significant increase in the cytoplasmatic and cellular volume, and a significant reduction in the nucleus-cytoplasm ratio as well as in the numerical cellular density. These results showed that the sodium cyclamate in pregnant rats led to retardation of fetal development and hepatic-cellular hypertrophy in the offspring, suggesting toxicity in liver of rat fetuses.

KEY WORDS: Sodium cyclamate; Fetal liver; Karyometry; Stereology.

\section{INTRODUCTION}

Cyclamate, derived from N-cyclo-hexyl-sulfamic acid (CHS), and amply utilized as a non-caloric artificial edulcorant in foods and beverages as well as in the pharmaceutical industry. It is odorless and soluble in water, alcohol and propylene glycol (Sain \& Berman, 1984) and more stable than aspartame and saccharine, and thus may submitted to variations in temperature. (Barlattani, 1970).

Cyclamate was discovered in 1937 at the University of Illinois, USA, by the graduate student Michael Sveda who accidentally perceived its sweet taste, 30 times sweeter than saccharine but without its bitter flavor (Audreith \& Sveda, 1944). Beginning in 1959, the Food and Drug Administration (FDA) added cyclamate to the list of safe substances, thus permitting its use as a non-caloric artificial edulcorant for diabetics. (Ahmed \& Thomas, 1992).
During the 1960s, the mixture of cyclamate and saccharine in a 10:1 proportion, drove an increase in the consumption of this substance in the USA to a level approaching 8.943 tons of cyclamate in 1969. (Burbank \& Fraumeni Jr., 1970).

In the following year, Price et al. (1970) evaluated the development of tumors in the bladder of rats treated with high doses of cyclamate, which was interpreted by the Food and Drug Administration (FDA) as a substance that possibly induces cancer. Subsequent to this study, the U. S. Department of Health, Education and Welfare (HEW) concluded that cyclamate did not presented any value in the treatment of obesity or diabetes (Egeberg et al., 1970) and its utilization became prohibited in the USA, remaining so to this day.

\footnotetext{
* Faculdade de Medicina de São José do Rio Preto (FAMERP), São José do Rio Preto, SP, Brazil.

*** Faculdade de Odontologia de Ribeirão Preto da Universidade de São Paulo (FORP-USP), Ribeirão Preto, SP, Brazil.
} 
However, the World Health Organization's Joint Expert Committee on food Additives approved the use of sodium cyclamate in 1977, as an alimentary additive in more than 40 countries including Brazil (Boop et al., 1986; Ahmed \& Thomas), although several experimental results from that era presented reasons for its non-utilization (Oser et al., 1968; Pitkin et al., 1970; Kroes et al., 1977).

Despite the affirmation of Assunção et al. (1994) that in Brazilian diabetics the consumption of this additive is less than $50 \mathrm{mg} / \mathrm{Kg}$ of body weight in relation to acceptable daily ingestion (Göttinger et al., 1968; Assunção et al.), the group which is expected to present elevated utilization of edulcorants, it is known that the saccharine substitution is growing, and can affect pregnant women, which represents a great risk, because according to Pitkin et al., sodium cyclamate can cross the placental barrier and approach a fetal concentration one fourth that of maternal one.

The present work describes fetal hepatic karyometric and stereological alterations detected in rats submitted to intraperitoneal administration of sodium cyclamate, during the gestational period. The objective of this study was to evaluate fetal hepatic karyometric and stereological alterations resulting from the intraperitoneal administration of sodium cyclamate, from the tenth to the fourteenth day of pregnancy, subdivided into the following items:

1. Evaluation of the intrauterine growth of the fetus by means of the fetal and placental weights and the length of the umbilical cord.

2. Karyometric evaluation of hepatocyte of rat fetuses.

3. Stereological evaluation of the rat fetal liver.

\section{MATERIAL AND METHOD}

In this study, the livers of ten rats were evaluated, five treated and five controls chosen at random, in which five rats that received from the 10th to 14th pregnancy day an intraperitoneal injection of sodium cyclamate at $60 \mathrm{mg} /$ $\mathrm{kg}$ of body weight (treated group) and five that received the same via saline solution $0.9 \%$ (control group). On the 20th pregnancy day, the animals of both groups were weighed, as were their placentas, on a precision balance; the length of the umbilical cords also were measured. After the laboratory processing were obtained semi-seriated $6 \mu \mathrm{m}$ cuts stained with hematoxilin and eosine.

From each animal selected, hepatocyte nuclei were evaluated with an optical microscope with camera lucida (H500 hund Wetzlar) and final magnification of 1240 times which contoured the elliptical structures on white sulfite paper with a black number 2 pencil. For the determination of the major (D) and minor (d) diameters with a millimeter ruler, the following karyometric parameters were obtained: mean geometric diameter, ratio of longest to shortest axis, perimeter, area, volume, ratio of volume to areas, eccentricity, shape factor, and contour index.

The same material was submitted to stereology, also by means of an optical microscope with a camera lucida and a preconized grade application by Merz (1968). A projection was completed in 20 different fields of 100 points each for a total of 2000 points for each element from the groups. As a consequence of this technique, the parameters obtained were: cytoplasmic volume, cellular volume, ratio of nucleus to cytoplasm, and numerical cellular density.

For statistical comparison of the morphometric results obtained in the treated and control groups, the non-parametric Mann-Whitney test was utilized.

\section{RESULTS}

The quantitative parameters for fetal weight, placenta weight and umbilical-cord length in both control rat fetuses (C) and those treated with sodium cyclamate (T) can be see in Table I as well as the statistical analysis.

Examination of Table I enables verification that all quantitative parameters presented significant statistical differences between groups. Treated animals present reduction in the three measures.

In Table II, mean differences in nuclear parameters are demonstrated for control (C) and treated (T) groups as well as the statistical analysis.

It can be observed that, of all the karyometric parameters presented, the seven which were statistically different from the control group were: major, minor and mean diameters $(\mu \mathrm{m})$, volume $\left(\mu \mathrm{m}^{3}\right)$, area $\left(\mu \mathrm{m}^{2}\right)$, perimeter $(\mu \mathrm{m})$ and the volume-area ratio. Conversely, the four data that did not show statistically significant differences were: majorminor diameter ratio, eccentricity, coefficient of form and contour index.

The above Table shows that there are increases in cytoplasmic and cellular volumes and a marked reduction in the nucleus-cytoplasm ratio as well as numerical cellular density, when the control and treated grouped are compared statistically. 
Table I. Mean values for fetal weight and placental weight $(\mathrm{g})$; umbilical-cord length $(\mathrm{cm})$ of control fetuses (C) and treated with sodium cyclamate (T). Mann-Whitney test.

\begin{tabular}{lcccc}
\hline Parameter & Control & Treated & $\mathrm{U}$ & $\mathrm{P}[\mathrm{U}]$ \\
\hline Fetal weight & 2.94 & 2.31 & $0^{*}$ & 0.004 \\
Placental weight & 0.44 & 0.29 & $0^{*}$ & 0.004 \\
Umbilical cord length & 2.12 & 1.93 & $0^{*}$ & 0.004 \\
\hline
\end{tabular}

$* \alpha<0.01$

Table II. Mean values for major, minor and mean diameters $(\mu \mathrm{m})$, and the ratio between major and minor diameter, volume $\left(\mu \mathrm{m}^{3}\right)$, area $\left(\mu \mathrm{m}^{2}\right)$, perimeter $(\mathrm{mm})$, volume-area ratio, eccentricity, shape factor and contour index for the liver of rat fetuses for control (C) and those treated with sodium cyclamate (T). Mann-Whitney test .

\begin{tabular}{|c|c|c|c|c|}
\hline Parameter & Control & Treated & $\mathrm{U}$ & $\mathrm{P}[\mathrm{U}]$ \\
\hline Major diameter & 11.58 & 12.69 & $0 *$ & 0.004 \\
\hline Minor diameter & 8.59 & 9.63 & $0 *$ & 0.004 \\
\hline Mean diameter & 9.94 & 11.02 & $0 *$ & 0.004 \\
\hline Major-minor diameter ratio & 1.37 & 1.34 & $8 \mathrm{~ns}$ & 0.21 \\
\hline Volume & 543.92 & 739.73 & $0 *$ & 0.004 \\
\hline Area & 79.09 & 97.12 & $0 *$ & 0.004 \\
\hline Perimeter & 31.9 & 35.27 & $0 *$ & 0.004 \\
\hline Volume-area ratio & 6.63 & 7.35 & $0 *$ & 0.004 \\
\hline Eccentricity & 0.64 & 0.62 & $9 \mathrm{~ns}$ & 0.274 \\
\hline Shape factor & 0.96 & 0.96 & 9 ns & 0.274 \\
\hline Contour Index & 3.62 & 3.61 & $10 \mathrm{~ns}$ & 0.345 \\
\hline
\end{tabular}

$* \alpha<0.001 \mathrm{~ns}=$ not significant

Table III. Mean values of nucleus-cytoplasm ratio, cytoplasmic volume (mm3), cellular volume $\left(\mu \mathrm{m}^{3}\right)$, numerical cellular density $\left(\mathrm{n}^{\circ} / \mu^{3}\right)$ of the liver of control rats $(C)$ and those treated with sodium cyclamate (T). Mann-Whitney test.

\begin{tabular}{lcccc}
\hline Parameter & Control & Treated & U & P[U] \\
\hline Nucleus-cytoplasm ratio & 0.314 & 0.216 & $3^{* *}$ & 0.028 \\
Cytoplasm volume & 1645.76 & 2533.97 & $0^{*}$ & 0.004 \\
Cellular volume & 2189.67 & 3273.7 & $0^{*}$ & 0.004 \\
Numeric al cellular density & 472262.6 & 307.146 & $0^{*}$ & 0.004 \\
\hline
\end{tabular}

$* \alpha<0.01 ; * * \alpha<0.05$ 


\section{DISCUSSION}

The possibility that sodium cyclamate could induce hepatic toxicity, was presented initially by Göttinger et al. ; Hagmüller et al. (1969) who observed that animals submitted to sodium cyclamate administered orally presented alterations such as cellular necrosis and accumulation of glycogen in the cytoplasm of hepatocytes.

Although many others authors have detected hepatic alterations induced by sodium cyclamate, (Boop et al.), some others studies did not verify evidence of hepatic toxicity, even in biopsies from the livers of rats, mice, dogs and monkeys (Richards et al., 1951; Taylor et al., 1968; Branton et al., 1973; Coulston et al., 1975), which could be related to edulcorant use.

Thus the present work corresponds to a fetal and karyometric-stereological quantitative evaluation of the liver of rat fetuses submitted to intraperitoneal injection of sodium cyclamate from the tenth to the fourteenth days of intrauterine life. During this phase, the liver is responsible for behaving as the hematopoietic structure in the rat. For this evaluation, the utilization of morphometric techniques were preconized, preceded by conventional techiniques to obtain the quantitative data on account of its role in the detection of physiopathological alterations amply described in the literature. (Tassinari \& Long, 1982) These methodologies have been adequately utilized for the study of different organs and tissues in various animal species. (Sala et al., 1981).

In relation to the quantitative results for the treated group, it was shown that the mean fetal weight (2.31g), mean placental weight $(0.29 \mathrm{~g})$ and mean umbilical-cord length $(1.93 \mathrm{~cm})$ were reduced compared to those of the control group, which were $2.94 \mathrm{~g}, 0.44 \mathrm{~g}$ and $2.15 \mathrm{~cm}$, respectively.

According to Pitkin et al., the fetal concentration of sodium cyclamate in pregnant women may reach $1 / 4$ of the maternal concentration as a function of this capacity to permeate the placental barrier. In this manner the quantitative alterations verified in this work are in accord with those of the latter author and yet in accord with Roby \& Soares (1993) who found that placental morphology, position and function can be utilized as a maturation index of the placenta; and Moessinger et al. (1982) who found that umbilical-cord length is one of the factors related to fetal growth. Thus reduction of its length could indicate diminished fetal movement in the gestation period on account of sodium cyclamate.

Regarding morphometric data, out of eleven karyometric parameters obtained from determination of major (D) and minor (d) axes, the follwing seven presented a statistically difference between two groups: major diameter, minor diameter, mean geometric diameter, volume, area, perimeter and the ratio between volume and area. classically, there is observed an evident increase in the size of the nucleus without simultaneously altering the form of hepatocyte nuclei since the ratio between the major and minor diameters, as well as eccentricity, coefficient of form and contour index do not present a significant statistical difference between groups.

Although some works affirm an absence of toxic effects from sodium cyclamate on organisms (Oser et al.; Takayama et al., 2002), many studies clearly demonstrate an injurious effect of this substance on cellular activity. (Cattanach, 1976; Sasaki et al., 2002) these studies show an alteration in the synthesis of cellular RNA and DNA, confirming what was initially proposed by Pitkin et al.

Stereological results of the present study ratify the propositions cited since, of the four parameters obtained from the application of stereological techniques, the nucleus-tocytoplasm ratio, cytoplasmic volume, cellular volume and cellular numerical density, all were statistically different in comparisons between the control and treated groups. These results present significant increases of cellular and cytoplasmic volume and reductions in both the ratio of nucleus to cytoplasm, as well as he number of cells per cubic millimeter, with the latter representes by numerical cellular density.

In agreement with Richards et al. in their study of different methods for administering sodium cyclamate in various animal species, there was no alteration in renal or hepatic functions in the groups studied. However, many of these presented inflammatory lesions and vacuolizations that, according to the author, are associated uniquely with the osmotic effect of edulcorant.

Branton et al. evaluated 60 mice which, divided into groups, received a diet of $0.7,1.75,3.5$ or $7 \%$ sodium cyclamate for 80 weeks. According to these authors, the effect in those fed the diet with $7 \%$ additive became evident since, among other alterations, all animals in the subgroup presented a reduced number of erythrocytes and a decreased concentration of hemoglobin.

In summary, this work represents a valuable contribution through its original karyometric-stereologic verification in the rat fetus liver, by detecting intense hepatic 
alterations resulting from intraperitoneal administration of sodium cyclamate. It can be concluded that sodium cyclamate administered intraperitoneally from the 10th to the 14th day of pregnancy causes: 1) diminished fetal weight, placental weight and umbilical-cord length compared to the control group, suggesting retardation of fetal development, and 2) hepatic cellular hypertrophy (cytoplasm and nucleus) with small-caliber sinusoids.

MARTINS, A. T.; AZOUBEL, R.; LOPES, R. A.; DI MATTEO, M. A. S.; ARRUDA, J. G. F. Efectos del ciclamato de sodio en el hígado fetal de ratas: estudios cariométrico y estereológico. Int. J. Morphol., 23(3):221-226, 2005.

RESUMEN: El ciclamato, es una substancia derivada del ácido N-ciclo-hexil-sulfámico, bastante usada como edulcorante no calórica en alimentos y bebidas, así como en la industria farmacéutica. El objetivo del trabajo fue evaluar los efectos del ciclamato de sodio en hígados de fetos de ratas, considerándose las alteraciones cariométricas y estereológicas. Fueron utilizadas 10 ratas adultas (Rattus norvegicus) variedad Wistar, con peso medio de $240 \mathrm{~g}$, siendo 5 el grupo control y 5 tratadas con ciclamato de sodio. Entre el $10^{\circ}$ y $14^{\circ}$ día de la preñez, 5 ratas recibieron una inyección diaria intraperitoneal de $60 \mathrm{mg} / \mathrm{Kg} / \mathrm{día}$ de ciclamato de sodio durante 5 días. En el $20^{\circ}$ día, los animales fueron sacrificados y los fetos fijados en solución de Alfac, incluidos en parafina, cortados a $6 \mu \mathrm{m}$ y teñidos com HE. Hubo aumento estadísticamente significativo en siete parámetros cariométricos (diámetros mayor, menor y medio, volumen, área, perímetro y relación área/volumen) en el grupo tratado con ciclamato de sodio comparado con el grupo control. Parámetros estereológicos mostraron aumento significativo en los volúmenes citoplasmático y celular y disminución significativa en la relación núcleo/citoplasma y densidad numérica celular. Los resultados mostraron que el uso del ciclamato de sodio en las ratas preñadas causó retardo en el desarrollo fetal e hipertrofia celular hepática en los fetos, sugerente de toxicidad en el hígado fetal de las ratas.

PALABRAS CLAVE: Ciclamato de sodio; Hígado; Cariometría; Estereología.

\section{REFERENCES}

Ahmed, F. E. \& Thomas D. B. Assessment of carcinogenicity of the nonnutritive sweetner cyclamate. Crit. Rev. Toxicol., 22:81-118, 1992.

Assunção, M. C. F.; Anderson, G. B. \& Cavalcanti, Z. C. H. Uso de adoçantes alternativos pelos diabético. JBM, 67:62-9, 1994.

Audreith, L. F. \& Sveda, M. Preparation and properties of some N-substituted sulphamic acids. J. Org. Chem., 9:89$101,1944$.

Barlattani, M. Rassegne sintetiche di terapia. Il problema dei ciclamati. Cl. Terap., 52:565-60, 1970.

Boop, B. A.; Sonders, R. C. \& Kesterson, J. W. Toxicological aspects of cyclamate and cyclohexylamine. Crit. Rev. Toxicol., 16:213-306, 1986.

Branton, P. G.; Gaunt, I. F. \& Grasso, P. Long-term toxicity of sodium cyclamate in mice. Food Cosmet. Toxicol., 11:735, 1973 .

Burbank, F. \& Fraumeni Jr, J. F. Synthetic sweetener consumption and bladder cancer trends in the United States. Nature, 227:296-7, 1970.

Cattanach, B .M. The mutagenicity of cyclamates and their metabolites. Mutat. Res., 39:1-28, 1976.
Coulston, F.; McChesney, E. W. \& Golberg, L. Long-term administration of artificial sweeteners to the Rhesus monkey (M. mulatta). Food Cosmet. Toxicol., 13:297, 1975.

Egeberg, R. O.; Steinfeld, J. L.; Frantz, I.; Griffith, G. C.; Knowles Jr, R. H.; Rosenow, E.; Sebrell, H. \& Van Itallie T. Report to the secretary of HEW from the Medical Advisory Group on cyclamates. JAMA, 211:1358-61, 1970.

Göttinger, E.; Hagmüller, K.; Hellauer, H. \& Vinazzer, H. The effect of cyclamate, a sweetening agent, on liver parenchyma, corresponding enzymes and blood clotting factors. Wein. Klin. Wschr., 80:328, 1968.

Hagmüller, K.; Hellauer, H.; Winkler, R. \& Zangger, J. New histological findings and further experimental data on the question of cyclamate tolerance in the guinea pig. Wein. Klin. Wschr., 81:927, 1969.

Kroes, R.; Peters, P. W. J.; Berkvens, J. M.; Verschuuren, H. G.; De Vries, T.H. \& Van Esch, G. J. Long-term toxicity and reproduction study (including a teratogenicity study) with cyclamate, saccharin and cyclohexylamine. Toxicology, 8:285-300, 1977.

Moessinger, A. C.; Blanc, W. A.; Marone, P. A. \& Polsen, D. C. Umbilical cord length as an index of fetal activity: 
experimental study and clinical implications. Pediatr. Res., 16:109-12, 1982.

Oser, B. L.; Carson, S. \& Vogin, E. E. Growth and reproduction studies with cyclamate-saccharin (10:1) in rats. Toxicol. Appl. Pharmacol., 12:290-1, 1968.

Pitkin, R. M.; Reynolds, W. A. \& Fiter, L. J. Placental transmition and fetal distribution of cyclamate in early human pregnancy. Am. J. Obstet. Gynecol., 108:104350, 1970.

Price, J. M.; Biava, C. G.; Oser, B. L.; Vogin, E. E.; Steinfeld, J. \& Ley, H. L. Bladder tumors in rat fed cyclohexylamine or high doses of a mixture of cyclamate and saccharin. Science, 167:1131-2, 1970.

Richards, R. K.; Taylor, J. D.; O’Brien, J. L. \& Duescher, H. O. Studies on cyclamate sodium (sucaryl sodium), a new non-caloric sweetening agent. J. Am. Pharm. Assoc., $40: 1,1951$

Roby, K. F. \& Soares, M. J. Trophoblast cell differentiation and organization: role of fetal placenta and ovarian signals. Placenta, 14:529-45, 1993.

Sain, O. L. \& Berman, J. M. Efectos adversos de edulcorantes en pediatria sacarina y ciclamato. Arch. Arg. Pediatr., 82:209-11, 1984.

Sala M. A. M.; Matheus, M. \& Valdeci V. A. A new stereological method for estimation: the thickness of a cellular layer on random sections. Mikroscopy Wien., 38:127-30, 1981.

Sasaki, Y. F.; Kawaguchi, S.; Kamaya, A.; Ohshita, M.; Kabasawa, K.; Iwama, K.; Taniguchi, K. \& Tsuda, S. The comet assay with 8 mouse organs: results with 39 currently used food additives. Mutat. Res., 519:103-19, 2002.
Takayama, S.; Renwick, A. G.; Johansson, S.; Thorgeirsson, U. P.; Tsutsumi, M.; Dalgard, D. W. \& Sieber, S. M. Long-term toxicity and carcinogenicity study of cyclamate in nonhuman primates. Toxicol. Sci., 53:339, 2002.

Tassinari, M. S. \& Long, S. Y. Normal and abnormal midfacial development in the cadmium treated hamster. Teratology, 25:101-13, 1982.

Taylor, J. D.; Richards, R. K.; Wiegand, R. G. \& Weinberg, M. S. Toxicological studies with sodium cyclamate and saccharin. Food Cosmet. Toxicol., 6:313, 1968.

Correspondence to: Prof. Dr. Reinaldo Azoubel

Faculdade de Medicina de São José do Rio Preto (FAMERP)

Av. Brigadeiro Faria Lima, 5416

CEP 15090-000

São gosé do Rio Preto - SP

BRAZIL

Tel.: +551732015712

Email:alex@feb.6r

Received: 15-01-2005

Accepted: 20-05-2005 